Revista de la red interuniversitaria de estudios sobre las literaturas rioplatenses contemporáneas en Francia

$14 \mid 2016$

Levrero

\title{
En torno a los corasanes
}

\section{Bartleby Lavalleja}

URL: http://journals.openedition.org/lirico/2311

DOI: 10.4000/lirico.2311

ISSN: 2262-8339

Editor

Réseau interuniversitaire d'étude des littératures contemporaines du Río de la Plata

Referencia electrónica

Bartleby Lavalleja, «En torno a los corasanes », Cuadernos LIRICO [En línea], 14 | 2016, Puesto en línea el 07 junio 2016, consultado el 19 abril 2019. URL : http://journals.openedition.org/lirico/2311 ; DOI : 10.4000/lirico.2311

Este documento fue generado automáticamente el 19 abril 2019.

\section{(c) $(1) \Theta \Theta$}

Cuadernos LIRICO está distribuido bajo una Licencia Creative Commons Atribución-NoComercialSinDerivar 4.0 Internacional. 


\title{
En torno a los corasanes
}

\author{
Bartleby Lavalleja
}

1 Los corasanes, posteriormente llamados "croissants" por los franceses, fueron inventados en Montevideo, en el año 1856, por Isidore Ducasse, "Conde de Lautréamont", y llevados a París por él mismo en esa travesía imprecisa y nebulosa que los investigadores no han logrado, hasta la fecha, verificar sin enloquecer.

2 A pesar de que los franceses reivindican para sí la invención de los "croissants" o medialunas, atribuyéndolas a un oscuro panadero de Decazeville, Jean Croissant (O Croix Sainte, según otros, que van más allá y le asignan a la medialuna un significado místico, esotérico o cabalístico, y al supuesto panadero un carácter simbólico, algo como el santo patrono de una secta ocultista que floreció en el sur de Francia, a mediados del siglo XIX), a pesar de las protestas inglesas (Sir Oliver Gallinworth asegura que el tocino, las medialunas y las obras de Shakespeare son incuestionables invenciones de los hermanos Bacon), y de la insinuación de parte del Diccionario de la Real Academia Española, de que bien podrían ser medialunas los indefinidos "bollos" citados en el Quijote, lo cierto es que, de acuerdo con el Registro de Patentes de nuestro país, los corasanes nacieron en el Río de la Plata y fueron el resultado de una larga serie de elaboraciones que culminaron con la genial torsión de puntas pergeñadas por Ducasse.

3 Antes de Ducasse los corasanes eran derechos e inevitablemente se perdían, deslizándose hacia el interior de la taza, al mojarlos en el café con leche. Se les llamaba "panecillos de orfebre"; Melanie Klein osa afirmar que la torsión impuesta a las puntas no se debió al natural afán de evitar que la factura se perdiera en el café, o su búsqueda por medio de cucharillas especiales, sino - atiéndase bien- a la "necesidad inconsciente de Ducasse de desvirtuar el carácter fálico de los panecillos de orfebre y administrarles esa forma uterina, para compensar la falta de su madre, y a causa de su indudable homosexualidad latente". La autora no ha leído seguramente los "Cantos de Maldoror", y proyecta en el montevideano su propia envidia ; por otra parte, confiesa en el tomo IV de sus Obras Completas no haber comido nunca un croissant, lo cual no deja de ser significativo.

4 Por último, cabe señalar que algunos autores, encabezados por James Atchik, ponen en duda la existencia del mismo Ducasse; afirman "hubo incuestionablemente un Isidore 
Ducasse que nació en Montevideo y un Isidore Ducasse que murió en París, con un intervalo de veinticuatro años", pero no puede asegurarse de que se trate de la misma persona; ni menos aún, que esta persona sea realmente el Conde de Lautréamont que escribió los “Cantos de Maldoror", los que, según dicen, tienen todas las características de una obra colectiva; y apelan nuevamente a la secta que estaría simbolizada por el panadero Croix Sainte, a la que no habrían sido ajenos Léon Bloy, Jalbert Klutch y Rubén Darío.

5 Nosotros nos mantenemos al margen de la polémica. Preferimos, con Agnes Peralta, "leer por las noches algunas páginas de Maldoror, y por las mañanas sumergir lentamente un corasán en el café con leche, y luego otro, y otro más ; el resto de la jornada no es más que vanidad y aflicción del espíritu."

Maldoror $\mathrm{N}^{\circ} 8$, diciembre 1972 